\title{
Effects of Automated Teller Machine on the Performance of Nigerian Banks
}

\author{
Jegede C.A. ${ }^{*}$ \\ Department of Accounting and finance, Lagos State University, Ojo, Nigeria \\ *Corresponding author: jegede_charles@yahoo.com
}

Received August 07, 2013; Revised August 24, 2013; Accepted February 07, 2014

\begin{abstract}
This study investigates the effects of ATM on the performance of Nigerian banks. Available studies have concentrated on the significant dimensions of ATM (automated teller machine) service quality and its effect on customer satisfaction with a bias against ATM producers. The study is motivated by the astronomical challenges confronting the proliferation of ATM infrastructure and attendant financial losss to banks which are often underreported. Also, there are serious debate on the relevance of ATM technology as most countries in the world are moving away from the virus technology to the more secured chip cards free of credit and debit frauds. Questionnaire was used to collect the data from a convenience sample of 125 employees of five selected banks in Lagos State with interswitch network. Therefore, data collected through the questionnaire were analyzed statistically by using the Software Package for Social Science (SPSS Version 20.0 for Student Version) and chi-square technique. The results indicate that less than the benefits, the deployment of ATMs terminals have averagely improved the performance of Nigerian banks because of the alarming rate of ATM fraud. Similarly, ATM service quality is less correlated to security and privacy of users and providers.The conclusion therefore is that banks should strive to increase their security layers to subvert the tricks of web scammers, limit the amount which customers may be allowed to withdraw at a time and provide electronic alerts to customers'phone for all transactions carried out on their bank accounts through ATMs and the provisions of extra security layer that can prevent third party to make use someone else's ATM card for unauthorized withdrawals electronically.
\end{abstract}

Keywords: ATM, bank performance, fraud, information technology

Cite This Article: Jegede C.A., "Effects of Automated Teller Machine on the Performance of Nigerian Banks." American Journal of Applied Mathematics and Statistics 2, no. 1 (2014): 40-46. doi: 10.12691/ajams-2$1-7$.

\section{Introduction}

In today's business world, globalization and international experience has become critically important. Banking industries can no longer get away with operating loosely connected groups of businesses that happen to be located around the world, but must strategically integrate their activities. Mitroff [1] stated that, only the banks, businesses, industries, and whole by societies that clearly understand the new rules of doing business in a world economy will prosper. Global competition in the banking sectors has forced management and executives to recognize that they must think differently about banking activities and management. As a global banking, the only way to succeed is to develop an effective global banking management system with personnel capable of designing and implementing transnational business strategies through the use of modern technology such as automated teller machines (ATMs).

Technology has tremendously stimulated expansion of the banking networks and range of the offered services during recent years. All banking services, such as electronic payments, loans, deposits, or securities have become heavily dependable on information and telecommunication technology. This is the main reason why banks are the biggest users of modern technology equipment. Due to the complexity of banking services, every opportunity to speed up their performance or to make them more accessible for customers is very well welcomed by banks. However with improvements of the quality of services, the important question appears if this process can provide the economic values for banks? Unfortunately not every increase in the customers' satisfaction transfers into the higher bank profits, especially in the case of very expensive investments in technology like automated teller machines (ATMs).

Although every banking operation requires some technology applications, researcher vary on the subject of the relationship between the level of employed automated teller machines, and the value of the banking efficiency increase. All researchers agree on the importance of ATMs for the further developments of the banking industry, but some of them have found lack of proportionality between the increased in the scale of technology utilization and the increase in banks profitability [2].

Automated Teller Machine (ATM), also known as a automated banking machine (ABM) or Cash Machine 
and by several other names, is a computerised telecommunications device that provides the clients of a financial institution with access to financial transactions in a public space without the need for a cashier, human clerk or bank teller. On most modern ATMs, the customer is identified by inserting a plastic ATM card with a magnetic stripe or a plastic smart card with a chip, that contains a unique card number and some security information such as an expiration date or CVVC (CVV). Authentication is provided by the customer entering a personal identification number (PIN). Using an ATM, customers can access their bank accounts in order to make cash withdrawals, credit card cash advances, and check their account balances as well as purchase prepaid cellphone credit.

Ogbuji, et al. [3] postulate that ATM allows a bank customer to conduct his/her banking transactions from almost every other ATM machine in the world. However, the spread of the machines has been generating a lot of heat, as customers face a splurge of frustration in using it; either the machines will not dispense cash, or debit transactions when cash is not dispensed or cards get stuck in them. Dapo [4] indicate that the proliferation of the machines is giving more concern. As with every other technological breakthrough the ATMs have generated astronomical challenges and problems for the beneficiaries of financial services in Nigeria. Most users of ATM have encountered the problem of Scam. Apart from epileptic services rendered by the machines, faceless crooks steal from the accounts of hundred of bank customers via the ATM technology. The fraudsters perpetrate this financial crime by stealing the personal identification number, PIN, a special secret code that grants access to the usage of the cards, and consequently, getting hold of the funds of the susceptible ATM users.

The relationship between banking efficiency and the use of ATM (Automated Teller Machine) is a complex one. This is because the overall levels of efficiency and productivity do influence the organization overall success [5]. This explains why most modern banking sectors develop ways of increasing organization and workers' efficiency. Some of these ways include goal setting, job enrichment, adoption information technology, globalization, training and development. All these represent several practical ways of increasing banking sector's performance, which could also be a reflection of institutions efficiency.

The achievements, goals, profit and attainment of banking sector depends largely on the proper management and technology such as ATM adopted in the banking activities. It's upon this basis that the level of efficiency, effectiveness and performance of banking sector and other organization is measured. The impact of ATM on the performance of banking institutions have been without some challenges. There have been near lack of empirical research efforts on the effect of ATM on performance of the providers, using FCMB as case study. Arguably, the most revolutionary electronic innovation in this country has been the ATM. In Nigeria, banks with ATM offerings have them networked and this has increased their utility to customers. The ATM has been the most successful delivery medium for consumer banking in this county. This call for investigation.

\section{Literature Review}

The banking system with all its complexities, challenges and opportunities touches virtually all aspects of the daily lives. Using a credit card to make a purchase, writing a personal or business check, paying bills and moving funds online or accessing funds through an automatic teller machine (ATM) are just a few examples of how people may participate daily in the banking system. Even the micro-finance banks provides banking-related services such as loans and check cashing in communities where those services are either not readily available or where consumers perceive the micro finance bank to be their best or only-banking alternative.

The techniques of managing of banking industries through the use of Automated Teller Machine (ATM) towards improving banking industry performance is a basket full where every financial institution is expected to pick that which is applicable to it. According to the Fannie Mae Foundation, automated teller machine as used in banking sector serve approximately 420 million transactions annually for a total of $\$ 3.3$ billion in gross annual revenues. In this article, we will address a number of topics including the types of services provided by full service banks, technological changes and the use and important of automated teller machine and fringe banking services.

ATMs are known by various other names including automatic banking machine (or automated banking machine particularly in the United States) (ABM), Automated Transaction Machine, Cashpoint (particularly in the United Kingdom), Money Machine, Bank Machine, Cash Machine, Hole-In-The-Wall, Autoteller (after the Bank of Scotland's usage), Cashline Machine (after the Royal Bank of Scotland's usage), MAC Machine (in the Philadelphia area), Bankomat (in various countries particularly in Europe and including Russia), Multibanco (after a registered trade mark, in Portugal), Minibank in Norway, Geld Automaat in Belgium and the Netherlands, and All Time Money in India.

Rose [6] cited by Abor, describes ATMs as follows: “an ATM combines a computer terminal, record-keeping system and cash vault in one unit, permitting customers to enter the bank's book keeping system with a plastic card containing a Personal Identification Number (PIN) or by punching a special code number into the computer terminal linked to the bank's computerized records 24 hours a day”. Once access is gained, it offers several retail banking services to customers. They are mostly located outside of banks, and are also found at airports, malls, and places far away from the home bank of customers. They were introduced first to function as cash dispensing machines. However, due to advancements in technology, ATMs are able to provide a wide range of services, such as making deposits, funds transfer between two or accounts and bill payments. Banks tend to utilize this electronic banking device, as all others for competitive advantage.

Using an ATM card, a debit card, or a credit card, bank patrons can electronically access their accounts and withdraw or deposit funds, make payments, or check balances. ATMs have eliminated the need to enter a bank for basic transactions and allow access to accounts at machines throughout the United States. Financial 
institutions started charging fees to use their ATMs in the mid-1990s, making the transactions very profitable for the host banks. The use of ATMs has cut service staff in traditional banks, impacting employment in the industry. As many machines are now commercially owned and leased in public venues, a technical industry for cresting, leasing, and maintaining the machines has developed [7].

Ogbuji, C. N. et al. (2012), observed the Automated Teller Machines (ATMs) is one of existing replacements of the cascading labour-intensive transaction system effected through what is popularly referred to as paperbased payment instruments. An automatic teller machine allows a bank customer to conduct his/her banking transactions from almost every other ATM machine in the world.The ATM, therefore, performs the traditional functions of bank cashiers and other counter staff. It is electronically operated and as such response to a request by a customer is done instantly.

The combined services of both the Automated and human tellers imply more productivity for the bank during banking hours. Also, as it saves customers time in service delivery as alternative to queuing in bank halls, customers can invest such time saved into other productive activities. ATMs are a cost-efficient way of yielding higher productivity as they achieve higher productivity per period of time than human tellers (an average of about 6,400 transactions per month for ATMs compared to 4,300 for human tellers Rose (1999). Furthermore, as the ATMs continue when human tellers stop, there is continual productivity for the banks even after banking hours.

Automated Teller Machine (ATM) machine works on the ATM cards, as when a user inserts an ATM card into the card reader component of the ATM machine, then it prompt for the authentication through ATM PIN (Personal Identification Number [8]. Each and every ATM machine is programmed with a unique TID (Terminal ID number) assigned to identify the ATM machine in different location. The ATM transactions are done through over the phone line via internet connection (lease line). All the ATM machines are globally interconnected with each other with the financial institutions through the global ATM network like Master Card, Maestro, Cirrus, Visa, etc. In back side of every ATM card some logos are printed which refers to the ATM network. So the ATM machine connects to ATM network through processing center and the card holder's bank. After the authorization step, if there is sufficient fund in the ATM card holder's account, then the transaction is completed successfully.

According to Ugwu [9], ATMs are set up to provide 24 hour services to bank customers, who cannot expect to be able to transact with banks in the same period of time. ATM technology allows customers carry out the abovementioned transactions using an ATM card, which could be a debit or a credit card. An ATM machine authenticates the card by reading and verifying the magnetic strip, card number, expiration date, and an already provided or preselected PIN number. Like with most technological advances, there is always a flaw which criminal-minded individuals identify and exploit to perpetuate fraud. Technology is being constantly evolved so that ATM transactions can be an enjoyable experience to its customers, especially if one has to pay for goods or services in cash by 1.00am in the morning and has no money.

\subsection{History of Automated Teller Machine IN Nigria}

The Automated Teller Machine (ATM) was introduced into Nigeria market in 1989, as a matter of fact the very first Automated Teller Machine (ATM) in Nigeria was first installed by National Cash Registers (NCR) for the defunct Society General Bank in 1987.

Adeoti [8] disclosed that in Nigeria, the first bank to introduce ATM was the Moribund Societe Generale (SGBN) in 1990. The trade name for SGBN's ATM was "Cash Point 24". One of the first generation banks then, First Bank Plc came on stream with their own ATM in December 1991, a year behind SGBN. They also gave a trade name "FIRST CASH" to their ATM. While that of SGBN was the drive-in-system, that of the First Bank ATM was through-the-wall. Access to ATM is through the use of Personal Identification Number (PIN) and a plastic card that contains magnetic strips with which the customer is identified. Banks usually hand over the PIN to the customer personally and the customer is usually instructed not to disclose the number to a third party. ATM card is about the size of a normal credit card and apart from the need to ensure its safety, its surface strips could be mutilated which may make the machine to reject it even though the PIN number is entered correctly.

Automated Teller Machine (ATM) are located in banks and customers convenience areas. This allow customers to drive up and complete financial transaction without ever leaving the safety of their belongings. Automated Teller Machine (ATM) are interconnected to allow anyone with a bank card, debit card, or credit card to have access anywhere in the world because each station is connected to an inter-bank network such as PULSE, PLUS, CIRRUS and LINK to mention but few.

The Figure 1, Figure 2 and Figure 3below show the different types and categories of ATM.

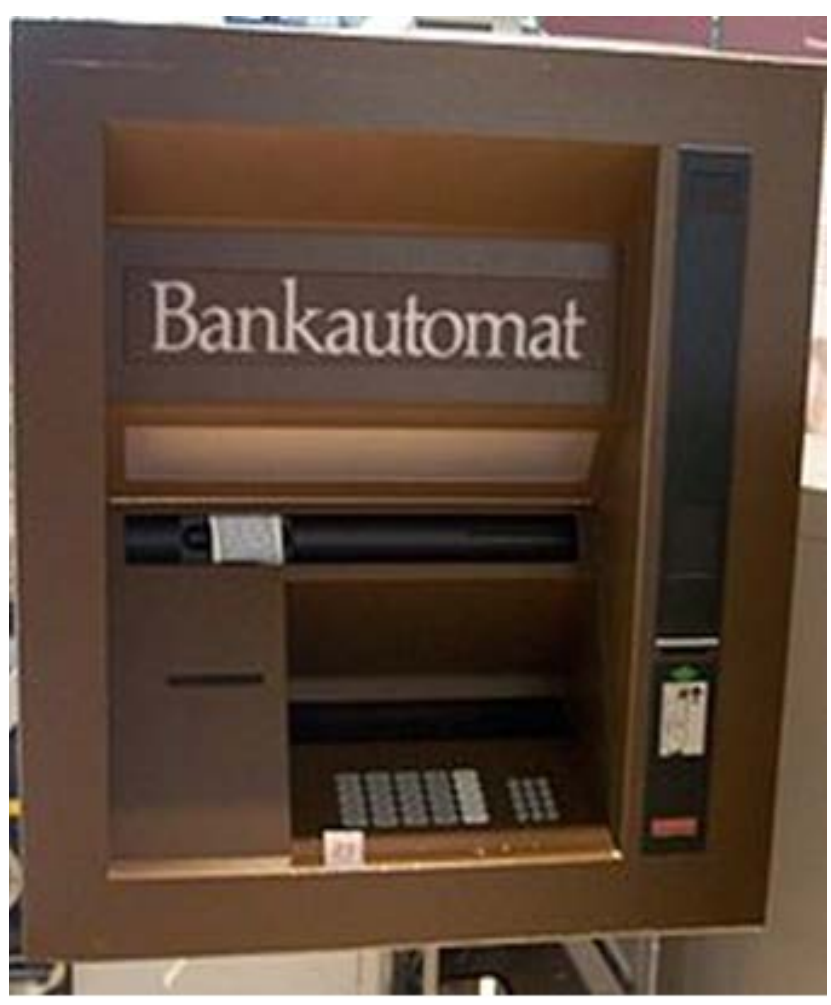

Figure 1. Sample of ATM Machine 


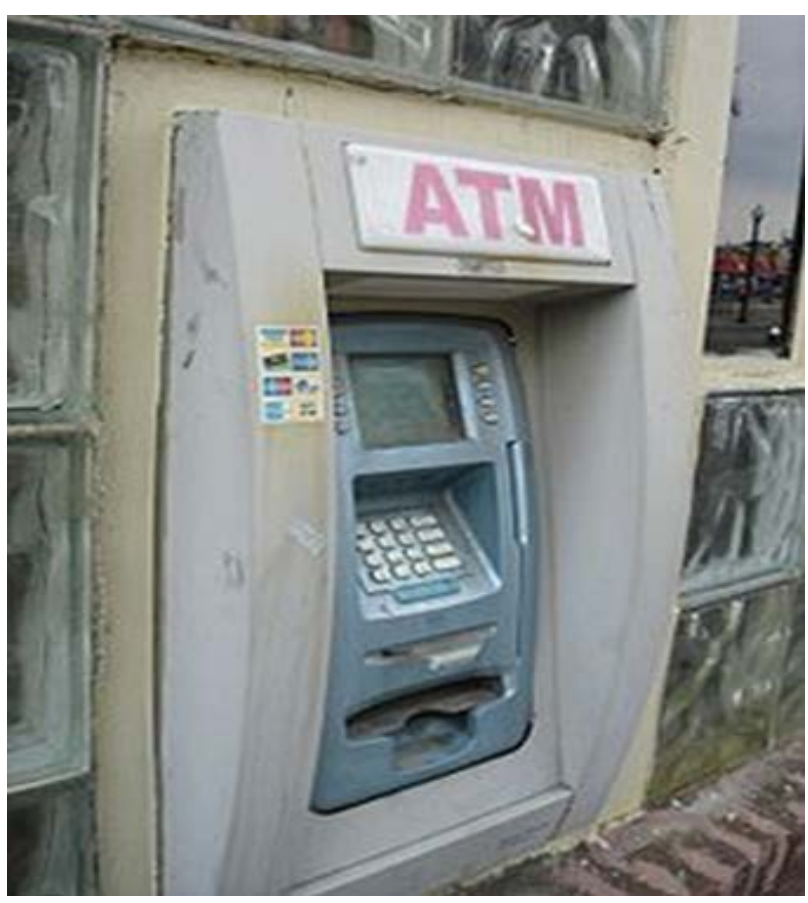

Figure 2. ATM Machine

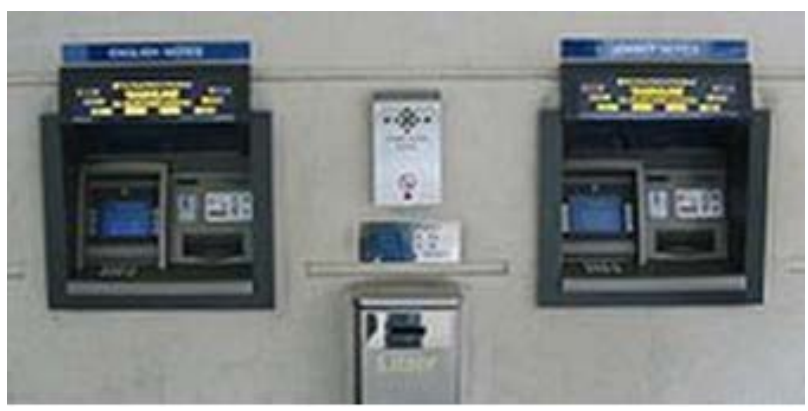

Figure 3. ATM Machine

Source: Compiled by the Author, 2012.

Other functions which the machines are capable of performing include:

(i) Printing of statements

(ii) Transfer of funds

(iii) Payment of bills

(iv) Cash advances

(v) Display of promotional messages (Adeoti, [10]).

\subsection{Impact of Automated Teller Machine on Banking Performance}

Bank customers in Nigerian have a collective sign-ofrelief when the Automated Teller Machine (ATM) was introduced as an instrument to aid banking operations in 2006. The introduction of the ATM by financial institutions changed the face of banking in Nigeria but with some inherent challenges.

According to [11] in his paper, Automated Teller Machine and Electronic Payment System in Nigeria, “ATM played a key role in any retail banks' efforts to use technology as a quality weapon to defeat competition”. Automated Teller Machine provides a major role in offeing conevenience, speedy and round the clock services.

Adeoti (2011), stressed that the use of ATM is safe and convenient. The ATM has made settlement of bills in the Nigerian banking system easy and saver. These benefits have resulted into phenomena growth in number of ATMs in Nigeria. The growth of ATMs in Nigerian banks has rose from 83\% in 2006 to 289\% in 2007 (Adeoti, 2011). Almost all banks introduced the ATM in their bank premises in 2007.

Another great impact of automated teller machine and information Technology is that it contributes immensely to the promotion of marketing banking services. With the aid of Information Technology, funds can be moved one account to another at the push of a button, essential information relating to a transaction could be made available thousands of miles away within minutes.

Today, banks are developing and deployed better personalized services through the use of automated teller machine. For example in Nigeria today, banks are providing customers with “Access Terminals"with which they (customers) can access their balances and view or print movement in their accounts. These are special services, enjoyed by special, customers, which has been impossible hitherto.

Among other schools that highligthed the usefulness of of ATM are $[12,13,14,15,16]$. They identified the advantages of ATM to the bank as follow: investment opportunities, reduction in costs (i.e. cost savings), effective service delivery, branding of shared network, satisfaction of customers and competitiveness etc. Moutinho [17] established that ATM facility resulted in speed of transactions and saved time for customers.

Other value added services of ATM include college fee payment, online collection of application fee, mobile top up, religion/trust Donation, bill settlement, insurance premium payment, funds transfer card to account, amongst others. Increased ATM usage is also helped by the fact that customers have now the flexibility of using ATMs of other banks, as most of the banks are part of major interbank networks. The interbank networks have brought together ATMs of several banks so that consumers would gain access to any of the participating banks' ATMs. Banks find it cheaper to pay membership fees to these networks as against setting up additional units in expensive-to-deploy areas. According to the Director, Switching and Processing, Interswitch cited in Siyanbola (2013), 16 out of the 26 million ATM cards currently in Nigeria were interswitch verve cards issued by over 16 commercial banks and well over 14 microfinance banks; while the remaining 10 million ePayment cards are shared by Mastercard and Visa, two global payment card players.

Many ATM vendors have devised specialised machines, embedded with biometric devices for authentication. Catering to the rural population, these machines have enabled them to interact with the machine in their local language and on a graphical user interface. The rural customer has seemed to accept this new medium. This has the potential to further widen the scope of ATM usage in the interior parts of the country. There is also interest towards white-label ATMs. Many companies are interested in this model, where the ownership of the ATM will not be with the banks but with third parties who deploy them and make money on fees charged on every transaction. The concept is prevalent in the American continent. Wide acceptance of ATMs by consumers, introduction of biometric ATMs, and increasing scope of value-added ATM services will maintain growth in the industry. 
However, the advantages of safety and convenience of ATM has unfortunately been lessened by the frauds that are perpetrated by 'plastic money'. The increase in number of customers using ATM has also increased the propensity to fraudulent practices by the ATMs fraud perpetrators. Ihejiahi [18] cited in [10] expressed concern about the lack of cooperation among banks in the fight to stem the incidence of ATM related frauds now plaguing the industry. He expressed that the silence among banks on ATM frauds makes it difficult for banks to share vital information that will help curb the menace.

Muhammad [19] postulates that the level of ATM fraud tend to have overshadowed the improvements which it has brought into the service delivery systems of Nigerian financial institutions. Similarly, [18] posit that despite the reality that the introduction of ATM terminals as a banking instrument was lauded by several customers as an alternative to the frustrating queues that characterized the country's banking hall, the situation today has changed drastically; it has become a source of worry to users and providers (banks) because the function it was meant to provide has been eroded seriously.

Obiano [19] blamed the menace of ATM frauds on indiscriminate issue of ATM card without regard to the customer's literacy level. According to him one of the frequent causes of fraud is when customers are careless with their cards and pin numbers as well as their response to unsolicited e-mail and text messages to provide their card details. Omankhanleu [20] opined that the current upsurge and nefarious activities of Automated Teller Machine (ATM) fraudster is threatening electronic payment system in the nation's banking sector with uses threatening massive dumping of the cards if the unwholesome act is not checked.

As with any device containing objects of value, ATMs and the systems they depend on to function are the targets of fraud. Fraud against ATMs and people's attempts to use them takes several forms. These include: Shoulder Surfing; Lebanese Loop; Using Stolen Cards; Card Jamming; Use of Fake Cards; Duplicate ATMs; Card Swapping: Diversion; and ATM Burglary (A Report on Global ATM Frauds, 2007). Some if not all are found in the Nigerian banking environment which ultimately undermined the effectiveness of ATM facility. ATM fraud is now a recurrent decimal that speaks ill of the Nigerian financial system which ought to be checkmated.

\subsection{Theoretical Framework}

During the 1960s, the influence which affluent nations had over less developed nations became a prominent topic of research. This study is based on Modernization theory assume that we live in a network society. These networks burst across territorial borders, rupturing the cultural and economic self-sufficiency once experienced by nations. The overall implication of these interconnections implies that societies co-exist with one another. At the same time, the once clear-cut separation between the sphere of national life and the international sphere has largely been broken down. Thus, this theory was considered to be more appropriate and suitable as it stresses the relationship between Automated Teller Machine and banking industry performance as a result of globalization which enhance political-economy and socio-economic development of a nation.

\section{Methodology}

For the purpose of the study, 5 banks were randomly samples from the 25 banks. These include EcoBank Plc, First City Monument Bank Plc, Zenith Bank, Guaranty Trust Bank Plc and Skye Bank Plc. The choice of the banks is that they are all new generation banks with large customers base. Questionnaires were served to 25 staff per sampled banks in Lagos metropolis. A Likert Scale of 5points was used to measure the level of agreement or disagreement by the respondents.

The response format is as follows:

VHE Very high extent

HE High extent

AE Average extent

LE Low extent

VLE Very low extent

Frequency distribution and Chi-square were used to analyze the data collected and examined the pattern of response to each variable under investigation. The Chisquare can be represented using the following formula:

$$
X^{2}=\frac{\sum(O-E)^{2}}{E}
$$

Where: $O=$ Observed frequency ; $E=$ Expected frequency

\section{Data Analysis}

A total of 125 questionnaires were administered and 100 were answered and returned which represented 80\% of the total respondents. Though the questionnaire covered various issues, only the relevant findings are reported in following tables.

Question 1: Automated Teller Machine (ATM) contribute immensely to effectiveness of banking sector.

Table 1. Effect of Automated Teller Machine (ATM) on effectiveness of banking sector

\begin{tabular}{|cc|c|c|c|c|}
\hline & Frequency & Percent & Valid Percent & Cumulative Percent \\
\hline Valid & Average extent & 17 & 17.0 & 17.0 \\
& High extent & 35 & 35.0 & 35.0 \\
& Very high extent & 48 & 48.0 & 17.0 \\
& Total & 100 & 100.0 & 100.0 \\
\hline
\end{tabular}

Source: Questionnaire returned

The analysis whether Automated Teller Machine increase banking sector efficiency in table above reveals that $48 \%$ of the sample size indicate very high extent, $35 \%$ of the population sample state high extent while $17 \%$ of the respondent say average extent and none of the respondent indicate low extent and very low extent. It 
could be deduced from the table that Automated Teller Machine contribute to the effectiveness of banking sector.
Question 2: To what extent as Automated Teller Machine stimulate growth of banking system.

Table 2. Impact of Automated Teller Machine on the growth of banking sector

\begin{tabular}{|c|c|c|c|c|c|}
\hline & & Frequency & Percent & Valid Percent & Cumulative Percent \\
\hline \multirow[t]{6}{*}{ Valid } & Very low extent & 4 & 4.0 & 4.0 & 4.0 \\
\hline & Low extent & 9 & 9.0 & 9.0 & 13.0 \\
\hline & Average extent & 20 & 20.0 & 20.0 & 33.0 \\
\hline & High extent & 30 & 30.0 & 30.0 & 63.0 \\
\hline & Very high extent & 37 & 37.0 & 37.0 & 100.0 \\
\hline & Total & 100 & 100.0 & 100.0 & \\
\hline
\end{tabular}

Source: Questionnaire returned

The above table also reveals that Automated Teller Machine stimulate banking industry growth when 37\% of the population sample indicate very high extent, follow by $30 \%$ of the respondent with high extent while $19 \%$ of the sample size says average extent and $10 \%$ state low extent, just few that $4 \%$ indicate very high extent to this effect. This shows that automated teller machine stimulate banking industry growth.

Question 3: Extent to which Automated Teller Machine speedily improve banking profitability.

Table 3. Impact of Automated Teller Machine on the profitability of banks

\begin{tabular}{|c|c|c|c|c|c|}
\hline & & Frequency & Percent & Valid Percent & Cumulative Percent \\
\hline \multirow[t]{6}{*}{ Valid } & Very low extent & 3 & 3.0 & 3.0 & 3.0 \\
\hline & Low extent & 9 & 9.0 & 9.0 & 12.0 \\
\hline & Average extent & 41 & 41.0 & 41.0 & 53.0 \\
\hline & High extent & 26 & 26.0 & 26.0 & 79.0 \\
\hline & Very high extent & 21 & 21.0 & 21.0 & 100.0 \\
\hline & Total & 100 & 100.0 & 100.0 & \\
\hline
\end{tabular}

Source: Questionnaire returned

From the table above, $42 \%$ of the sampled respondent indicated that Automated Teller Machine speedily improve profitability of banking to an average. This would indicate that banks staff are also aware of various challenges and fraud confronting the ATM facility. In fact, observation in the ATM points of most banks reveals that most customers experienced several cases of issues using ATM Machines either the machines will not dispense cash, or debit transaction when cash is not dispensed or cards get stuck into them and so on. These challenges have made ATM users to dissatisfied about the facility. Therefore, it can can be deduced that Automated Teller Machine has averagely improve banking industry profitability.

Question 4: Extent to which Automated Teller Machine ATM influence fraud in banking sector.

Table 4. Effect of Automated Teller Machine on fraud control in banking sector

\begin{tabular}{|cc|c|c|c|c|}
\hline & & Frequency & Percent & Valid Percent & Cumulative Percent \\
\hline Valid & Average extent & 13 & 13.0 & 13.0 & 21.0 \\
& High extent & 21 & 21.0 & 66.0 \\
& Very high extent & 66 & 66.0 & 13.0 \\
Total & 100 & 100.0 & 100.0 \\
\hline
\end{tabular}

Source: Questionnaire returned

Table above shows that Automated Teller Machine increase fraudulent in banking industry when $66 \%$ of the respondents indicate very high extent follow by $21 \%$ state high extent and $13 \%$ says average extent while none of the respondent indicate low extent and very low extent. From the table, it is clear that Automated Teller Machine increase fraudulent in banking industry as there are various forms of ATM scams.

\section{Hypothesis Testing}

The only hypothesis tested in this paper is to find out whether ATM frauds significantly affect the patronage of banks by those affected.

Test: $H_{0}$ : ATM facility have not significantly improved bank performance.

$H_{1}$ : ATM facility have significantly improved bank performance.

To test the hypothesis, we use Table 3 above. From the table, the computed value of $X^{2}=47.84$, while the critical value at 5\% significance level and a degree of freedom of 6 is 12.59. Since the critical value is greater than the $X^{2}$ value; we therefore reject the alternative hypothesis and accept the null hypothesis that ATM facility have significantly improved bank performance.

\subsection{Findings of the Study}

The study finds that Automated Teller Machine contribute to the effectiveness of banking sector. The tremendous growth and development of technological advancement has been the driving force of the market nowadays. The deployment of ATM facilitieshas revolutionized the banking sector. The Nigerian banks are aggressively promoting issue and use of ATM cards, credit cards, debit cards, and smart cards to enhance their performance and kill competition.

It also finds that Automated Teller Machine stimulate banking industry growth. This is expressed in the number 
customers using the ATMs. However the number of transaction per ATM remains a significant measure of the efficiency of these ATMs.Such transaction volumes can also be used to measure the kind of returns banks are getting from the regular patronage of their ATMs.

The high level of ATM fraud and scam is threatening the continual usage of the ATM by the users. These have become a source of worry to users and providers (banks) because the function it was meant to provide has been eroded seriously. A lot need to be done to create confidence in the minds of customers about the benefits and security of the automated delivery channels. Lack of use of ATM channels is expressed in lack of confidence characterized by ineptitude, lack of knowledgeable programmers and security experts that could guide and implement a secure transaction channel regardless of the level of education of the ATM card users.

Also, the absence of direct interaction with bank staff has increased customers' apprehensions about the perceived risk ATM delivery channels. To reduce the customers concerns about perceived risk because of security and privacy concerns, the bank should improve the quality of interaction with the customers to alleviate these apprehensions with a view to improve ATM service quality.

\section{Conclusion and Recommendations}

The paper reveals that Automated Teller Machine is important and very effective, and its discussion is not whether it is desirable or not, but to determine how the emerging technologies can be better annexed and channeled to promote banking sector growth, more productivity, more trade, improve banking records keeping, greater modernization and better living standard among Nigerians. The activities of banking industry has been able to rise up, thus, the advent of Automated Teller Machine has enable bank management and investors aware of some of the techniques being used by their foreign counterpart in achieving competitive advantage.

In view of the findings and problems associated with the use and introduction of Automated Teller Machine in banking industry which significantly influence economic growth, promote trading system, national income, and general welfare of the people, the following recommendations are suggested:

1. Government should protect financial institution by creating laws, which must be followed accordingly to enable them to improve in performance and activities.

2. Banking managers and government should properly adopt strategy that will encourage businessmen and general public in using automated teller machine which will improve effectiveness and efficient of the banking sector.

3. In a way of promoting the banking sector and micro finance banks, government should hold firm the laws on ATM fraudsters and scammers so as to boost economic of the nation.

4. The banks can employ customized software that records relevant information on ATM cards so that banks can establish whether unauthorized transaction has taken place or not.

\section{References}

[1] Mitroff, I. I. (2003). Do not Promote Religion under the Guise of Spirituality. Organization, 10(2), 375-377.

[2] Thakor, A. V and Olazabal, N. (2002) Banking: The IT Paradox. McKinsey Quarterly 1(1): 45-51.

[3] Ogbuji, C. N. et al. (2012). Analysis of the Negative Effects of the Automated Teller Machine (ATM) as a Channel for Delivering Banking Services in Nigeria. International Journal of Business and Management 7, No. 7; April 2012.

[4] Dapo, A. A. (2008). The impact of ICT on professional practice in the Nigerian construction industry. The Electronic Journal of Information Systems in Developing Countries. 24(2), p1-19.

[5] Paul, D.R. (1998). Towards a more efficient use of payment instruments. Available online at

http://www.econ.kuleuven.ac.be/ew/academic/intecon/Degrauwe/ PDG.

[6] Giddens, E. (2008). A first look at communication theory. New York: McGraw Hill

[7] Rose, P. S. (1999). Commercial bank management. Boston, Irwin/McGraw-Hill.

[8] Aditi, O. (2013). Working of Automated Teller Machine (ATM). Avalable at

http://www.techs24x7.com/blog/working-of-automated-tellermachine-atm/.

[9] Ugwu, E. (2008). CBN, banks to tackle ATMs' hitches. Retrieved April 25, 2013, from http://www.guardiannewsngr.com.

[10] Siyanbola, T.T. (2013). The effect of cashless banking on nigerian economy. eCanadian Journal of Accounting and Finance, 1(2): 9-19.

[11] Adeoti, J.A. (2011). Automated Teller Machine (ATM) Frauds in Nigeria: The Way Out. Journal of Social Sciences, 27(1): 53-58.

[12] Ebiringa, O. T. (2010). Automated Teller Machine and Electronic Payment System in Nigeria: A Synenthesis of the Critical Success Factors. Journal of Sustainable Development in Africa, 12 (1): 7186.

[13] Maiyaki A. U. and Mokhtar S. S. M (2010) Effects of electronic banking facilities, employment sector and age - group on customers choice of banks in Nigeria. Journal of Internet Banking and Commerce, Vol. 15(1), April.

[14] Lovelock, C. H. (2000). Functional integration in service: understanding the links between marketing, operations, and human resources. In Swartz, T.A. and Iacobucci, D.

[15] Chung, W.C.C., A.Y.K. Yam, M.F.S. Chan. (2004). Networked enterprise: A new business model forglobal sourcing. International Journal of Production Economics 87 267-280.

[16] Asif Khan, M. (2011). An Empirical Study of Automated Teller Machine Service Quality and Customer Satisfaction in Pakistani Banks. European Journal of Social Sciences, 13 (3): 333-344.

[17] Cabas, M. G. (2001). A History of the Future of Banking: Predictions and Outcomes. Retrieved September 2, 2012, from http://www.hass.berkeley.edu/finance /CMWpaper.pdf.

[18] Moutinho, L. and Smith, A. 2000. Modelling bank customer satisfaction through mediation of attitudes toward human and automated banking, The International Journal of Bank Marketing 18(3): 124.

[19] Ihejiahi R 2009. How to fight ATM fraud online. Nigeria Daily News, June 21, P. 18.

[20] Muhammad, A. K. (2009). An empirical study of automated teller machine service quality and customer satisfaction in Pakistani banks. European Journal of Social Sciences, Vol. 13 No.3, pp. 333-344.

[21] Adeyemi, A. (2010). Winning customers' confidence: The new banking focus. The Guardian, May 26 p. 25.

[22] Obiano W 2009. How to fight ATM fraud. online Nigeria Daily News, June 21, P. 18

[23] Omankhanlen Odidison 2009. ATM fraud rises: Nigerians groan in Nigeria. Daily News, Sunday, June 21, pp. 8-10.

[24] A Report on Global ATM Frauds (2007). Available online at http://www.icmrindia.org/casestudies/catalogue/Business\%20Rep orts/BREP041.htm. 